\title{
Slippery Wood: Low Friction and Low Wear of Modified Beech Wood
}

\author{
O. Waßmann ${ }^{1}$-S. I.-U. Ahmed ${ }^{1}$
}

Received: 26 December 2019 / Accepted: 19 March 2020 / Published online: 2 April 2020

(c) The Author(s) 2020

\begin{abstract}
This paper investigates the tribological and related properties of naturally modified beech wood (Fagus sylvatica). The modifications were performed on steamed beech wood using a variety of treatments consisting of drying, heating in an aqueous solution, impregnation with liquefied animal glue as well as beeswax followed by compression and various combinations thereof. Results indicate that an impregnation in liquefied animal glue followed by mechanical compression to $62 \%$ of the original volume leads to an increase in hardness of more than $160 \%$ as compared to steamed beech wood alone. The frictional properties of this natural polymer were further examined by sliding the wood samples against 100Cr6 (DIN 1.3505) steel spheres. Beeswax-impregnated and compressed samples showed a reduction in friction of $90 \%$ compared to steamed beech wood, with values in the regime of PTFE, over a sliding distance of $10 \mathrm{~km}$ with a normal load of $10 \mathrm{~N}$ and sliding speed of $0.1 \mathrm{~m} / \mathrm{s}$. Unlike PTFE, the low friction was also accompanied by a low specific wear rate of around $3.9 \times 10^{-7} \mathrm{~mm}^{3} / \mathrm{N} \mathrm{m}$. This study demonstrates the enormous potential of modified woods as an all-natural, non-toxic, renewable, and biodegradable material to replace synthetic polymers in technical applications with practically no environmental loading.
\end{abstract}

Keywords Modified wood $\cdot$ Low friction $\cdot$ Low wear $\cdot$ Synthetic polymer substitute $\cdot$ Green tribology

\section{Introduction}

Tribological materials using synthetic polymers such as polytetrafluoroethylene (PTFE) as well as their composites exhibit low friction against various materials, but are characterized by a relatively low wear resistance compared to harder materials, such as ceramics [1] or hard coatings [2]. Also, a large number of micro wear particles are formed in these synthetic polymers [3], which are subsequently released into the environment. Moreover, substances used for the synthesis of polymers can be harmful to human health and the environment [4]. One way to prevent the release of such micro-polymer particles is to use tribological materials that consist of purely natural, renewable, and biodegradable materials. An ideal candidate is wood.

Wood has been used for centuries in the construction of buildings and bridges, furniture, floor covering, musical instruments, and in the transportation industry, including

O. Waßmann

ol.wassmann@ostfalia.de

1 Faculty of Mechanical Engineering, Ostfalia University of Applied Sciences, Salzdahlumer Str. 46/48, 38302 Wolfenbüttel, Germany the construction of aircraft [5]. Investigations have been undertaken by the automotive industry to use wood-metal composite material in the bodywork sector [6]. Wood has even found its way in bearings in the form of hydro turbine bearing made from oil-impregnated maple wood [7]. In its native form, wood is an inhomogeneous, porous, and anisotropic material consisting of vessels, libriform fibers, and parenchymal cells [8]. Neglecting the pores, their contents, and accompanying substances, wood consists for the most part of three components: cellulose, hemicellulose, and lignin [8]. Cellulose and its compounds form the backbone that is mechanically responsible for the tensile strength [8]. The hemicellulose ensures the connection of cellulose and lignin [9]. An increase in lignin causes an increase in compressive strength [8]. Schwab [10] determined that a linear relationship exists between density and hardness of hardwoods. Many other wood properties are directly related to density [11]. Wood is strongly influenced by parameters such as humidity and temperature. For example, hardness and strength are significantly reduced with increasing humidity and/or increasing temperature $[12,13]$.

Besides using native wood, derivatives of wood such as particleboards are also quite popular and form a field of study of their own [14]. Another alternative to using native 
wood is to modify wood by different techniques. Scholz et al. [15] were able to increase the Birnell hardness of thermally modified wood impregnated with wax. Strengthenhancing properties were achieved by cold-rolling process [16]. However, according to Ref. [11], compressed materials are susceptible to swelling with increasing humidity. Song et al. [17] showed that hydrophobization could be achieved by delignification and subsequent compression. This treatment resulted in an increase in strength and hardness. Other studies based on delignification and subsequent densification have been applied for ultrathin membranes for acoustic speakers [18] as well as for fire retardant wood materials [19]. In an alternative process, Frey et al. [20] used vacuumassisted filling with epoxy prior to compression. An additional hydrophobization and increase in the bending strength were the main objectives of this study.

The impregnation of wood can also impact its tribological properties. In an early study, Vorreiter [21] examined selflubricating machine bearings that were impregnated with oil. However, in water, this resulted in a high loss of oil due to a strong capillary effect and the higher binding capacity of water compared to the used oils. In another investigation, Sathre and Gorman [22] filled maple and lime tree woods with oils, waxes, as well as fats and varied the speed and load in wear tests conducted against steel. In that study, high load and low speed resulted in the highest wear of the woodsteel collective. An additional enrichment with graphite did not affect the wear behavior. However, samples with an increased density showed a decreasing wear rate. According to [23], increased wear resistance was demonstrated by the impregnation of Falcataria moluccana wood with hexamethylene diisocyanate. Kim et al. [24] filled woods of the genus Paulownia with engine oil SAE30, PEG, and epoxy resin. Epoxy resin showed a significant increase in friction values, with SAE30 and PEG causing a reduction in friction. The lowest Coefficient of Friction ( $\mathrm{CoF})$ of 0.36 was measured for PEG-filled wood.
This paper presents a simple, yet effective, method of producing a natural polymer made from wood and other substances that are all-natural, non-toxic, renewable, and biodegradable. Even the micro-particles produced during use are completely biodegradable. Experiments indicate this material to be a viable alternative to low friction polymers and, at the same time, offer a real opportunity to deal responsibly and sustainably with resources.

\section{Materials and Methods}

The wood material used in this study was steamed beech wood with initial dimensions of $40 \times 18 \times 36 \mathrm{~mm}^{3}$ and moisture content of $9 \pm 1 \% \mathrm{RH}$. The samples were further processed according to Table 1 . Kiln-Drying was carried out at $100{ }^{\circ} \mathrm{C}$ for $48 \mathrm{~h}$ in an oven. In this study, impregnation was achieved by immersing the samples in the desired medium at $70{ }^{\circ} \mathrm{C}$ for $48 \mathrm{~h}$. Impregnation using vacuum techniques were not used in this paper. Animal glue (glutine glue-GG, Dictum) was used for impregnation. This glue is essentially a waste product derived primarily from animal bones [25]. Additionally, pure beeswax (Dictum) was also used for impregnation. Both materials were first dissolved in liquid. For this, GG was placed in room temperature water for an hour for swelling. This was followed by heating up to $70{ }^{\circ} \mathrm{C}$ in a water bath. The mixing ratio was $50 \mathrm{wt} \%$ water and $50 \mathrm{wt} \%$ GG. Beeswax, on the other hand, was heated to $70{ }^{\circ} \mathrm{C}$ together with ethanol in a water bath. A mixing ratio was around $50 \mathrm{wt} \%$ beeswax and $50 \mathrm{wt} \%$ ethanol. In the preparation of the samples consisting of GG mixed with beeswax, a ratio of $1 / 3 \mathrm{wt} \% \mathrm{GG}$, $1 / 3 \mathrm{wt} \%$ water, $1 / 6 \mathrm{wt} \%$ beeswax, and $1 / 6 \mathrm{wt} \%$ ethanol was used. Mechanical compression of the impregnated wood samples was carried out using a $U$-shaped device (Fig. 1). The samples were compressed vertically with a stamp to $62 \%$ of the original volume. This degree of compression

Table 1 Processing steps performed on beech wood

\begin{tabular}{|c|c|c|c|c|c|c|c|}
\hline Processing step & $\mathrm{AD}$ & GR-COA & WA-IM & $\begin{array}{l}\text { COM\&GR- } \\
\text { COA }\end{array}$ & GG-IM\&COM & WA-IM\&COM & $\begin{array}{l}\text { GG-WA- } \\
\text { IM\&COM }\end{array}$ \\
\hline Kiln-drying & & & $\mathrm{X}$ & & $\mathrm{X}$ & $\mathrm{X}$ & $\mathrm{X}$ \\
\hline Impregnation/plasticization & & & $\mathrm{X}$ & $\mathrm{X}$ & $\mathrm{X}$ & $X$ & $X$ \\
\hline Compression & & & & $X$ & $\mathrm{X}$ & $X$ & $\mathrm{X}$ \\
\hline Oven drying & & & $\mathrm{X}$ & $X$ & $X$ & $X$ & $X$ \\
\hline Manual finishing & $\mathrm{X}$ & $\mathrm{X}$ & $\mathrm{X}$ & $\mathrm{X}$ & $\mathrm{X}$ & $\mathrm{X}$ & $\mathrm{X}$ \\
\hline Conditioning & $\mathrm{X}$ & $\mathrm{X}$ & $\mathrm{X}$ & $\mathrm{X}$ & $\mathrm{X}$ & $\mathrm{X}$ & $\mathrm{X}$ \\
\hline Coating & & $\mathrm{X}$ & & $\mathrm{X}$ & & & \\
\hline Tribological measurement & $\mathrm{X}$ & $\mathrm{X}$ & $\mathrm{X}$ & $\mathrm{X}$ & $\mathrm{X}$ & $X$ & $\mathrm{X}$ \\
\hline
\end{tabular}

$A D$ as delivered, $G R-C O A$ graphite coated, WA-IM beeswax impregnated, $C O M \& G R-C O A$ compressed \& graphite coated, $G G-I M \& C O M$ animal glue impregnated and compressed, $W A-I M \& C O M$ beeswax impregnated and compressed, GG-WA-IM\&COM animal glue and beeswax impregnated and compressed 
Fig. 1 Wood sample in the natural (upper) and in the compressed state (lower) was determined to be the maximum achievable compression with a 5 ton press without composition altering processes, such as those mentioned in [17]. Subsequent drying was carried out in an oven at $65^{\circ} \mathrm{C}$ for $48 \mathrm{~h}$ or $200{ }^{\circ} \mathrm{C}$ for $1 \mathrm{~h}$, where the mechanically compacted parts remained in the compressed state throughout the drying stage. As a result of this drying process, the lumens are compressed to such an extent that no cavities could be discerned on the compacted wood samples using light microscopy. The medullary rays in this state show a stronger contrast to the remaining brown material (Fig. 1). The final dimension of the wood samples after cutting the pressed sample for the tribological investigations was $20 \times 20 \times 10 \mathrm{~mm}^{3}$ and for the Brinell hardness measurements was $20 \times 20 \times 20 \mathrm{~mm}^{3}$. The samples were then conditioned at $\mathrm{RH}=50 \%$ and a temperature $T=23{ }^{\circ} \mathrm{C}$ (according to DIN 50014-23/50$1)$, until a weight difference between subsequent measurements yielded a value of $\Delta \mathrm{m}<0.1 \%$. Following this, corrections of the plan parallelism were carried out manually using a precision file for some of the samples. For the

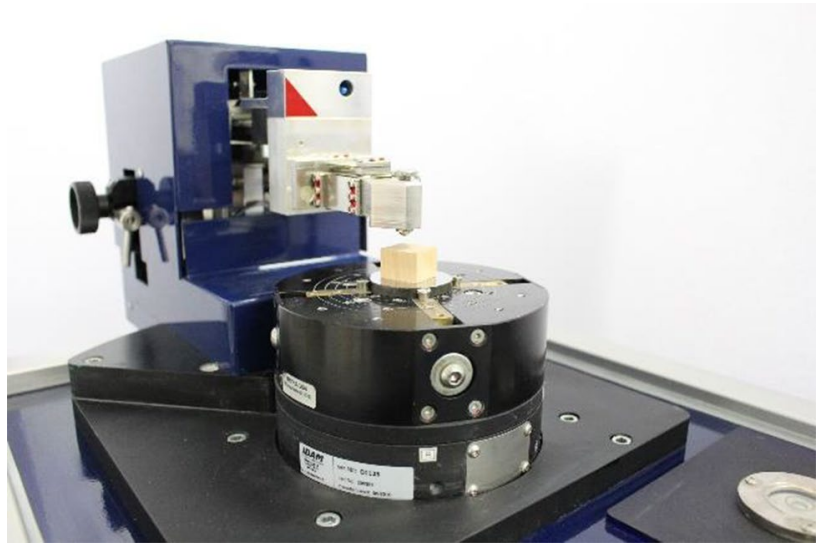

Fig. 2 Standard ball-on-disk tribometer used for tribological investigations

samples coated with graphite, graphite powder with an ultrafine grain (AMG GRAPHITE) was used, which was applied with a normal force of $5 \mathrm{~N}$ under rotation. The quantity of coated graphite determined through weighing before and after coating was about $1 \mathrm{mg} / \mathrm{cm}^{2}$.

Impregnation with graphite powder in an aqueous solution was attempted. In this attempt, the graphite powder was seen to only fill the larger lumes and not penetrate the bulk material completely. Other filling techniques, such as vacuum impregnation, did not provide satisfactory results. The coating method was then used to provide a better comparison to the impregnated samples.

Tribological investigations were performed using a standard ball-on-disk tribometer (Fig. 2). The counterbody in each case was a 100Cr6 (DIN 1.3505, AISI 52100) stainless steel ball (Red-Hill SA) of $6 \mathrm{~mm}$ diameter. The sample wood specimens $\left(20 \times 20 \times 10 \mathrm{~mm}^{3}\right)$ were mounted on a hardened $100 \mathrm{Cr} 6$ disk.

The test parameters used for all the tribological experiments were as follows: normal force $F_{\mathrm{N}}=10 \mathrm{~N}$ parallel to the longitudinal direction, sliding distance $s=10,000 \mathrm{~m}$, and sliding speed $v=0.1 \mathrm{~m} / \mathrm{s}$; samples were rotated in a clockwise direction and perpendicular to the $(\mathrm{R} \times \mathrm{T})$ directions, as shown in Fig. 3. The measuring environment was enclosed in a plexiglass (PMMA) box with a silicone seal. During testing, the temperature was always in the range of $20 \pm 2{ }^{\circ} \mathrm{C}$ and the relative humidity was maintained at $\mathrm{RH}=50 \pm 2 \%$ using two separate saturated salt solutions in combination: sodium chloride and magnesium nitrate. The analysis of the wear track was carried out using light microscopy (Keyence VHX-500) and a stylus profilometer with a $2 \mu \mathrm{m}$ diamond tip (DIAVITE DH-8). Wear profile as well as microscopy were performed $24 \mathrm{~h}$ after the tribological experiments to take into account any reverse deformations due to visco-elastic effects. Each experiment was repeated at least three times to ensure reproducibility. 


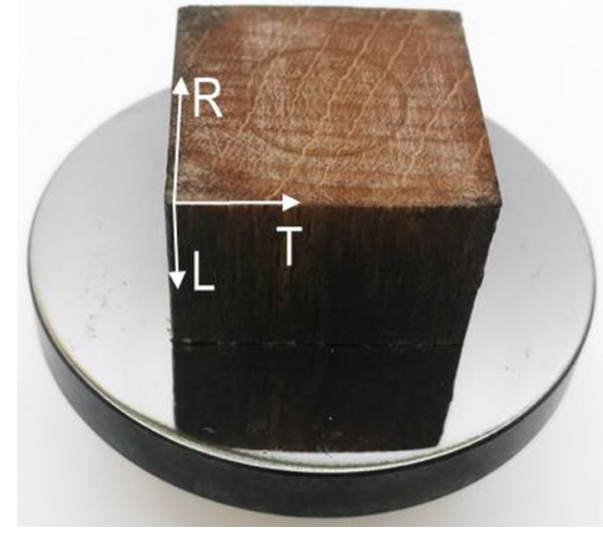

Fig. 3 Sample with wear track after a tribological measurement ( $L$ longitudinal, $T$ tangential, $R$ radial)

Hardness tests were performed on a hardness testing rig (Reicherter Briviskop BL 1-1). The tests were carried out in accordance with EN 1534. The subsequent observation and measurement of the ball marks were carried out with a light microscope. Weighing was performed with a precision micro scale (Kern ABT 220-5DM).

\section{Results and Discussion}

\subsection{Density and Hardness}

The Brinell hardness as a function of wood density for the variously prepared wood samples is shown in Fig. 4. For each modification, three wood samples were measured. The scattering of the measured density values was smaller than the symbols used in the figure.

According to Kollmann [12], the Brinell hardness of untreated wood lies in a range of 59 to $88 \mathrm{~N} / \mathrm{mm}^{2}$ (as shown in Fig. 4). The values of the as-delivered beech wood samples deviate only marginally from this range. For wood compressed to $62 \%$ of the original value, a linear relationship between hardness and density is observed, in agreement with results found in Ref. [10]. A deviation from this linear relationship occurs, however, in samples filled with animal glue or beeswax. The highest density of $1.21 \mathrm{~g} / \mathrm{cm}^{3}$ was measured for beeswax-filled samples. However, with $75 \mathrm{~N} / \mathrm{mm}^{2}$, these samples exhibit the lowest hardness of all the modified woods; a linear correlation between hardness and density does not occur here. Scholz and Krause [15] report a predominant increase in the hardness in the axial direction of their wax-filled woods. This assumption also is only partially true when comparing AD and WA-IM samples. Although the scattering is lower and the average hardness has increased somewhat due to the modification, the values are in the scattering range of the $\mathrm{AD}$ samples. For

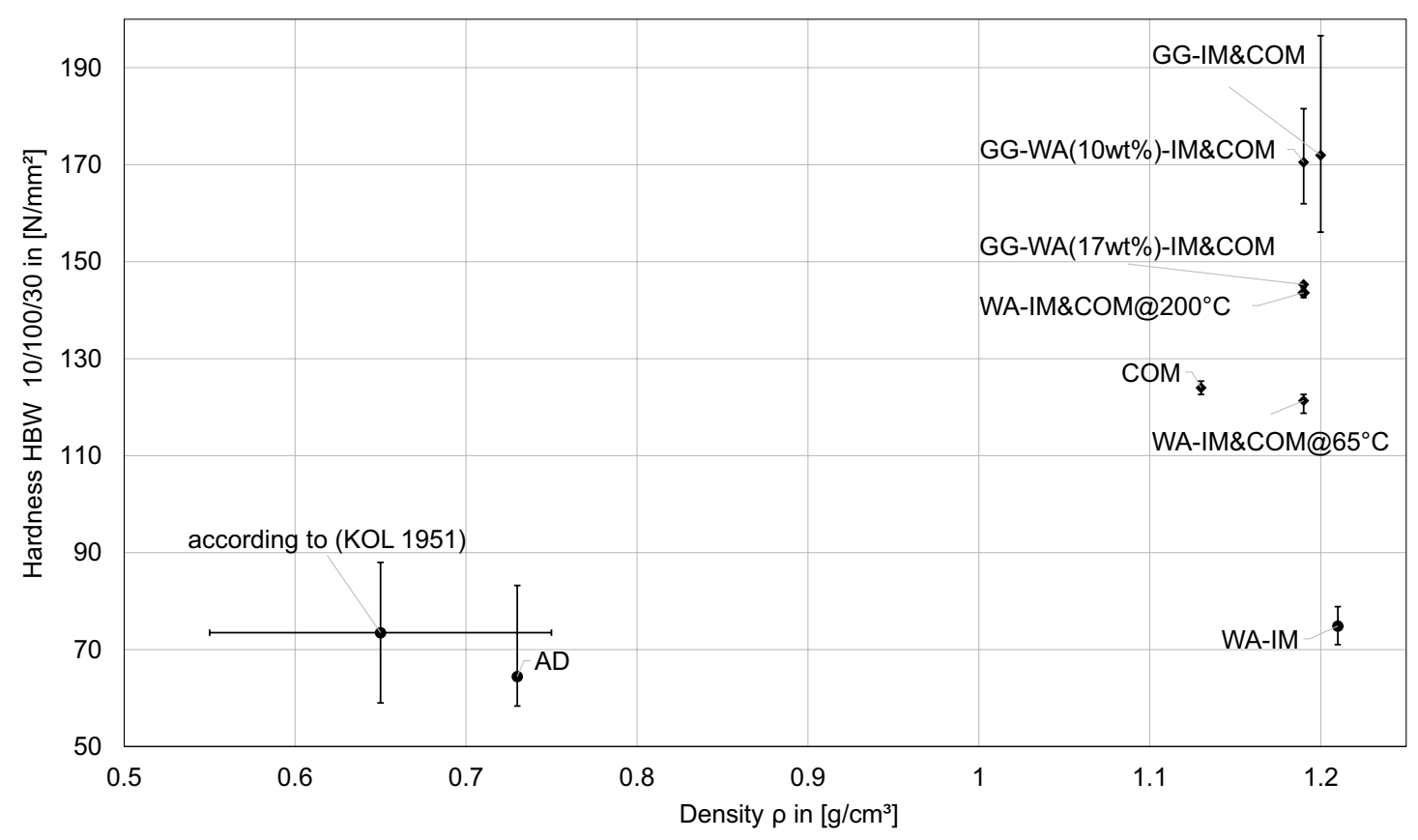

Fig. 4 Brinell hardness versus sample density for as-delivered steamed and variously modified beech wood. All the samples were conditioned at $\mathrm{RH}=50 \%$ and $T=23^{\circ} \mathrm{C}$ according to DIN 50014-23/50-1 prior to performing the density as well as hardness measurements 
compacted wood, filling with wax leads to a slight decrease in hardness for samples dried at $65^{\circ} \mathrm{C}$ (Fig. 4). For samples dried at $200{ }^{\circ} \mathrm{C}$, however, a slight increase in hardness is observed (Fig. 4).

The addition of animal glue to the wax clearly increases the hardness. This can be observed down to a wax content of $10 \%$. From this concentration onward, no clear difference with only filling with animal glue could be identified due to the fact that the scattering values of the two modifications overlap. Overall, it can be stated that an increase in average hardness with animal glue of about $160 \%$ is achieved compared to the uncompressed, unfilled beech wood samples.

The samples only filled with beeswax (WA-IM) are in the scattering range of untreated wood. The depicted increase in hardness of unfilled compressed wood (COM) can be attributed to an increase in the cell wall fraction per area and the resulting decrease in the porosity [9]. This decrease in porosity enables the formation of dipole and $\mathrm{H}$-bonds between adjacent cellulose chains [8]. The small decrease in hardness of the beeswax-impregnated and compressed samples (WA-IM\&COM@65 ${ }^{\circ} \mathrm{C}$ ) can be explained by a weakening of the attractive forces due to shielding of the cellulose chains upon filling. The slight increase in the hardness of (WA-IM\&COM@ $200{ }^{\circ} \mathrm{C}$ ) is in agreement with the results of Skyba [26], where thermal treatment at $180{ }^{\circ} \mathrm{C}$ for compressed wood leads to an increase in hardness in the longitudinal and radial direction.

The decrease of hardness with filling was not observed for the animal glue-filled samples (GG-IM\&COM, GG-WA(10 wt $\%)$-IM \&COM, GG-WA(17 wt\%)-IM\&COM) because here a novel composite matrix with the existing fibers is formed. The bonds formed by animal glue between the constituent $\mathrm{OH}, \mathrm{NH}_{2}$, and $\mathrm{COOH}$ groups and wood [27] could also have a positive effect. The additional binding forces between the glue-wood collective make it difficult for the individual fibers to "spread", resulting in a hard composite material. If this material is now subjected to a pressure on the face side, the fibers do not buckle much, because the lumens are filled with animal glue; instead, the fibers support each other. This supports the observation that GGIM\&COM exhibits the highest hardness of all the animal glue-filled samples.

\subsection{Tribology}

\subsubsection{Friction}

An overview of the average CoF of the examined wood samples is listed in Fig. 5. Steamed wood has the maximum CoF of 0.3 after $100 \mathrm{~m}$ and 0.37 after $1000 \mathrm{~m}$ sliding distance. Measurements were discontinued after reaching this distance. As can be seen in the figure, graphite-coated woods always exhibit a higher $\mathrm{CoF}$ than beeswax-impregnated woods up to $100 \mathrm{~m}$ sliding distance. The friction of the graphite-coated variant shows a run-in behavior up to $100 \mathrm{~m}$, which is characterized by a decreasing friction value. Towards the end of the measurements, in the range of 9 to $10 \mathrm{~km}$, friction increases. Within the measuring distance of $10 \mathrm{~km}$, the CoF value ranges between 0.12 and 0.16 . On the other hand, wax-impregnated samples exhibit a lower $\mathrm{CoF}$ ranging between 0.04 and 0.08 up to a sliding distance of $100 \mathrm{~m}$. A particular feature in this grouping is that WA-IM samples and GG-WA(17 wt \%)-IM\&COM samples show an increase in the $\mathrm{CoF}$ with increasing sliding distance. The GG-WA(17 wt\%)-IM\&COM variant, however, has the greatest variation over the course of sliding and the highest $\mathrm{CoF}$

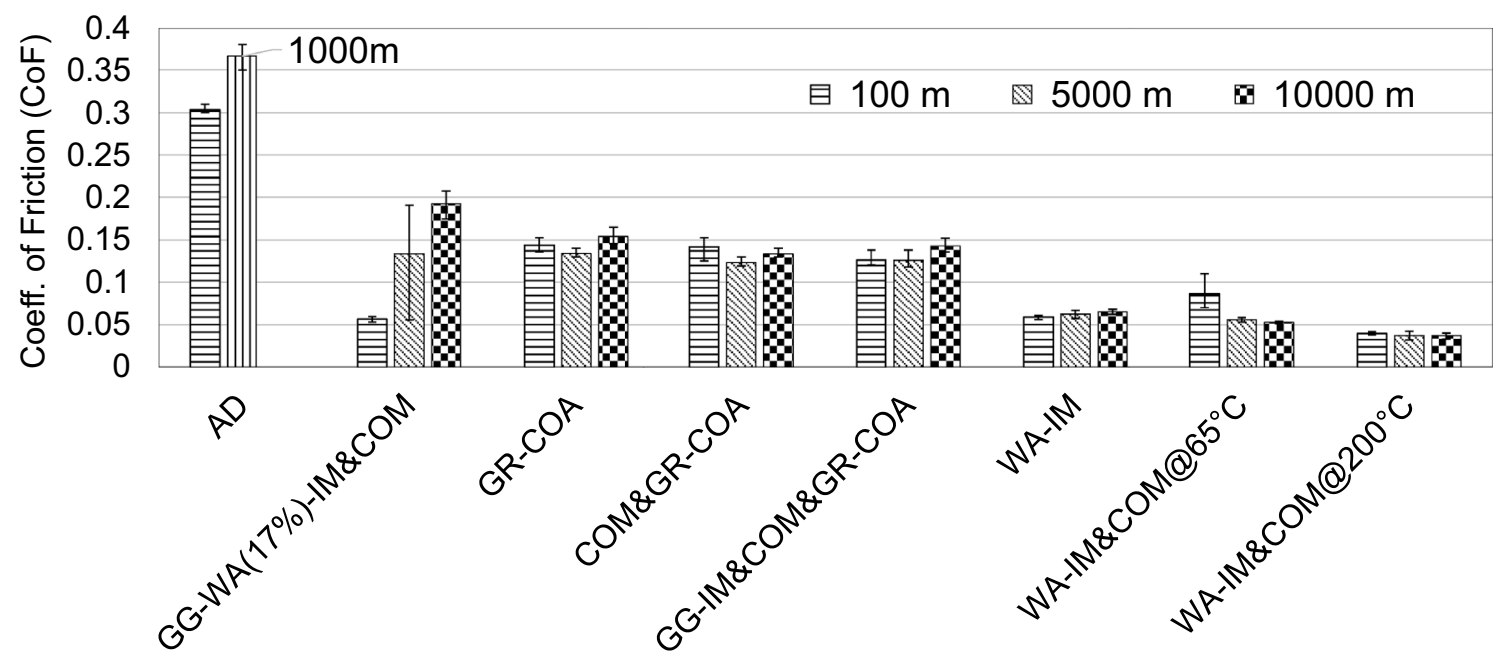

Fig. 5 Average CoF derived from three measurements per variant after sliding distances of $100 \mathrm{~m}, 5000 \mathrm{~m}$, and $10000 \mathrm{~m}$ (Exception: AD with $1000 \mathrm{~m}$ ) 
of the modified samples at the end of the measurement. Both WA-IM\&COM variants showed a continuous improvement in friction right up to the end of the measurement. The waxfilled samples with a drying temperature of $200{ }^{\circ} \mathrm{C}$ reached the lowest $\mathrm{CoF}$ values ranging between 0.03 and 0.04 .

Representative $\mathrm{CoF}$ values vs. sliding distance from asdelivered and modified beech wood are shown in Fig. 6. The as-delivered samples have a pronounced run-in in a range of 0 to $100 \mathrm{~m}$ followed by strongly oscillating CoF values around 0.3 whereby this increases slightly with increasing sliding distance. Modified samples, on the other hand, exhibit a considerably longer run-in phase up to around $2000 \mathrm{~m}$. The CoF of these samples is at least $50 \%$ lower and the further evolution of the CoF is much more homogeneous.

One group is formed by the graphite-coated samples. Here, while COM\&GR-COA shows a slightly lower CoF compared to GR-COA and GG-IM\&COM\&GR-COA, it caused a measurement stop in two out of five measurements (when the CoF value increases above 0.3). In general, the different graphite-coated variants are very similar in terms of the course of friction. They start with a CoF of approx. 0.15 and complete their running-in phases at approx. $1000 \mathrm{~m}$. The further course is characterized by a steady increase in the friction, which ranges between 0.12 and 0.15 .

Significantly lower $\mathrm{CoF}$ values were recorded for the wax-impregnated samples. These have initial maxima between 0.04 and 0.11 . With the exception of
GG\&WA(17 wt\%)-IM\&COM, the further course is very steady and lies in a range of values from 0.03 to 0.06 . Similar CoF values were determined for GG\&WA(17 wt \%)IM\&COM up to approx. $2000 \mathrm{~m}$. After that sliding distance, the CoF curve becomes more unstable and is characterized by a sharp increase up to a value of 0.19 . At the end of the measurement, the absolutely lowest CoF of 0.03 can be assigned to the WA-IM\&COM@200 $\mathrm{C}$ variant. This low CoF value and the steady curve indicates an intact lubrication system and represents a reduction in friction of approx. 90\% compared to untreated wood. This CoF value is even better than PTFE and UHMWPE against 100Cr6 under similar conditions.

An explanation for the highly fluctuating course of natural samples could be due to wear particles in the measuring track resulting in periodic three-body formations. The reduced friction of the graphite-coated samples is due to the structure of the graphite. The hexagonal layer lattice structures in the ambient medium air have very low binding energies between the individual planes and, thus, slide well over one another [28]. Figure Table $2 \mathrm{a}-\mathrm{c}$ provides illustrative examples of graphite-coated samples with a gradual increase in friction. Only very scarce residues of graphite are still visible in the wear track. Thus, the CoF increase of the graphite-coated samples could be attributed to decreasing quantity of lubricant in the wear track. In general, the modification by means of graphite is

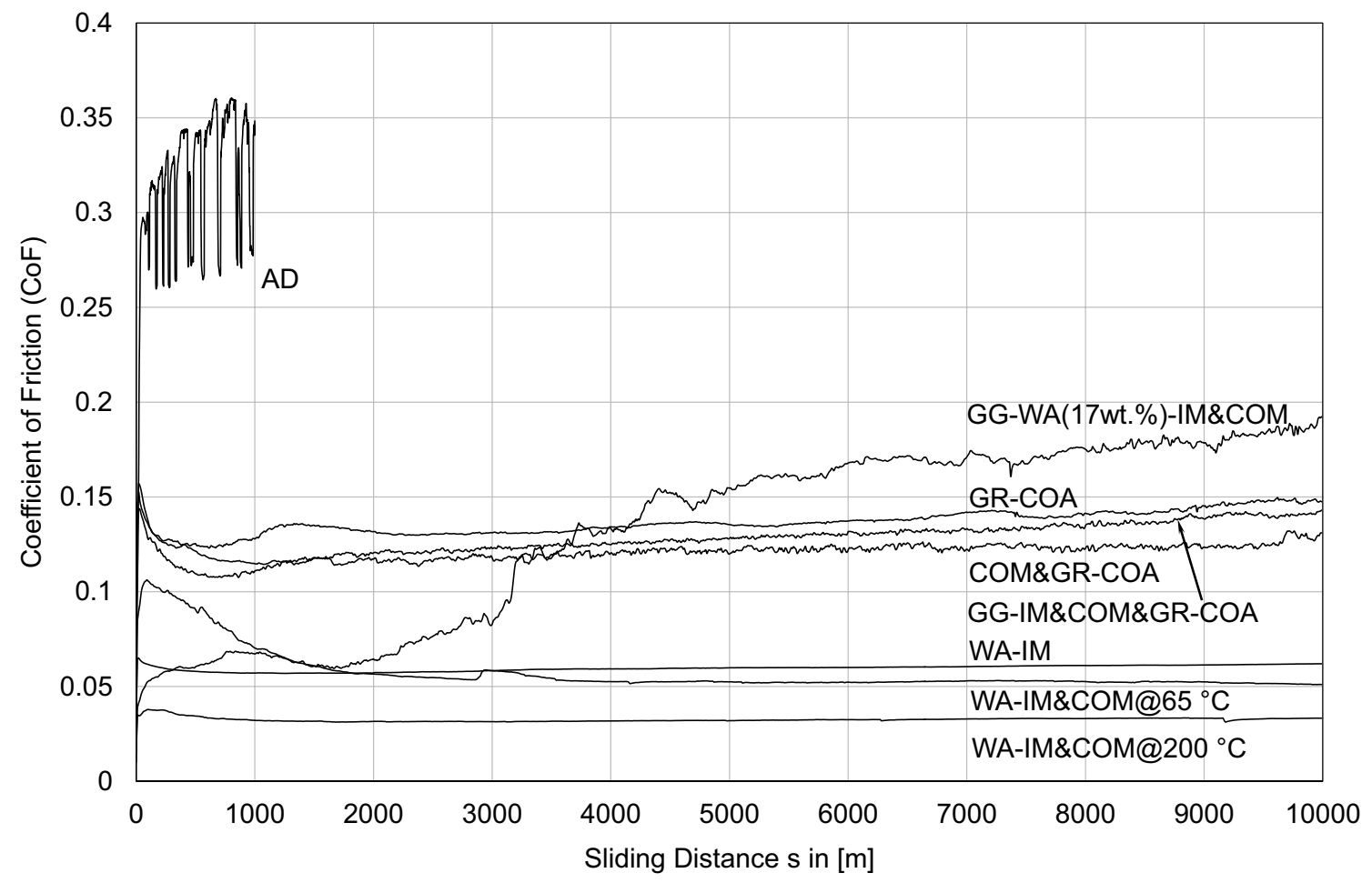

Fig. 6 Representative coefficients of friction of natural and modified beech wood 
Table 2 Wear tracks of modified woods after 10,000 m

(a) GR-COA

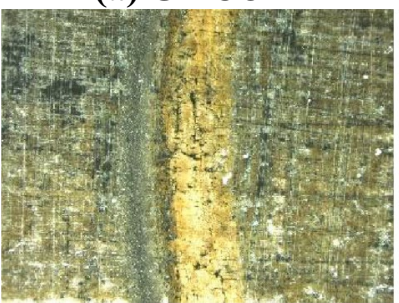

(d) WA-IM

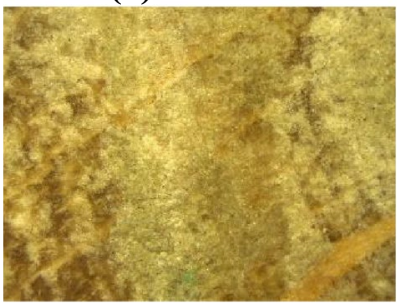

$500 \mu \mathrm{m}$ (b) COM\&GR-COA

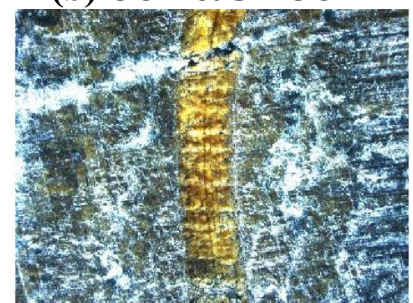

(e) WA-IM\&COM $@ 65^{\circ} \mathrm{C}$

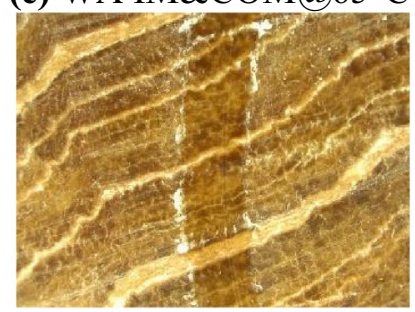

(c) GG-IM\&COM\&GR-COA

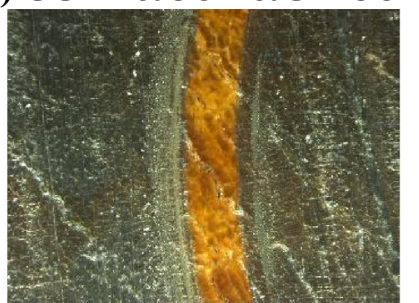

(f) GG-WA(17wt.\%)-IM\&COM

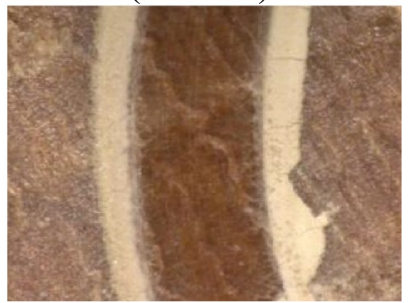

characterized by the accumulations of wear particles next to the measuring track.

Unlike graphite, beeswax is not a solid lubricant. Instead, beeswax consists of long-chain alcohols, which are esterified with fatty acids [29-31]. These adhere well to the friction partners and, due to their low shear strength, provide the low CoF observed in Figs. 5 and 6.

In the sample variant GG-WA(17 wt $\%)-I M \& C O M$, beeswax is present in a significantly lower proportion, which explains the higher friction behavior.

\subsubsection{Wear}

The measured wear in this study is primarily the result of plastic contact deformation and particle removal. In Fig. 7, the specific wear rate $(k)$ is plotted against the CoF. The specific wear rate, $\mathrm{k}$, is defined here according to $[32,33]$ as,
$k=\frac{W_{\mathrm{v}}}{s \cdot F_{\mathrm{N}}}$,

where $W_{\mathrm{V}}$ is the wear volume in $\mathrm{mm}^{3}$, s the sliding distance in $\mathrm{m}$, and $F_{\mathrm{N}}$ the normal load in $\mathrm{N}$. Consequently, $k$ is given in $\mathrm{mm}^{3} / \mathrm{N} \mathrm{m}$. The desired value of $k$ lies (as indicated) in the lower left corner of the diagram area (Fig. 7). The highest specific wear rates are found for the uncompressed samples and the variant GG-WA(17 wt\%)-IM\&COM. Despite similar hardness values of WA-IM and GR-COA, the maximum wear at $6.7 \times 10^{-6} \mathrm{~mm}^{3} / \mathrm{N} \mathrm{m}$ occurs for WA-IM. With $5.9 \times 10^{-6} \mathrm{~mm}^{3} / \mathrm{N} \mathrm{m}$, the second strongest wear occurs for GG-WA(17 wt\%)-IM\&COM. In direct comparison to the measurement track from WA-IM, a significantly higher proportion of wear particles can be found next to the measurement track. From a qualitative perspective, WA-IM has the largest plastic contact deformation. Conversely,

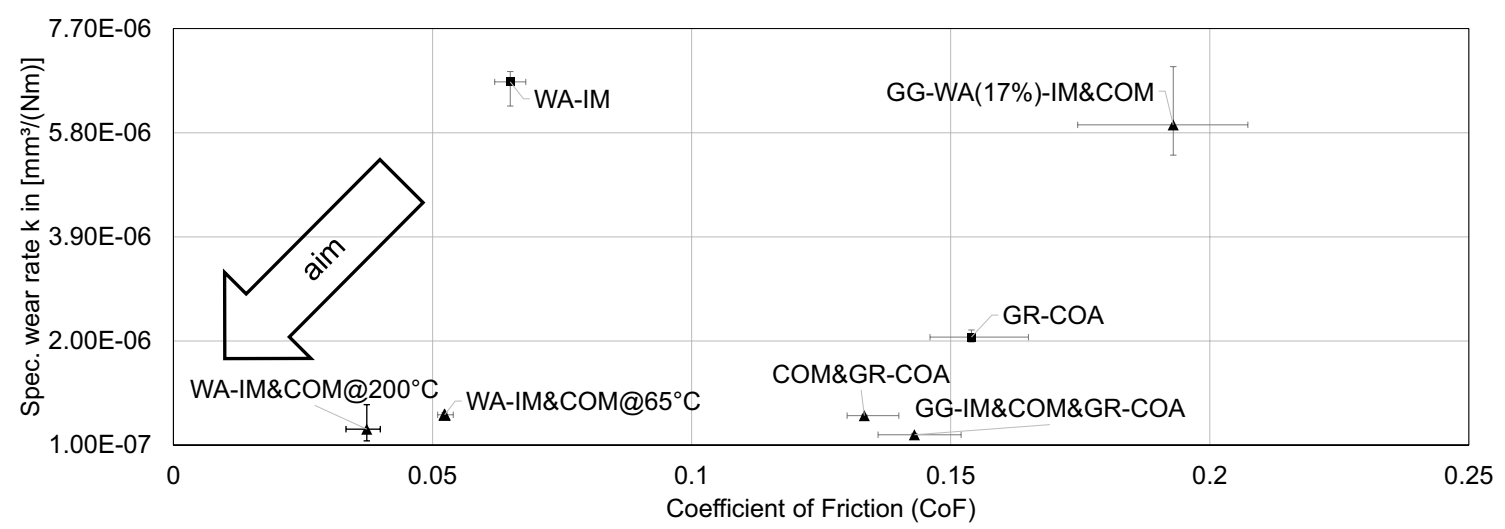

Fig. 7 Spec. wear rate $k$ versus average friction coefficient after 10,000 m 

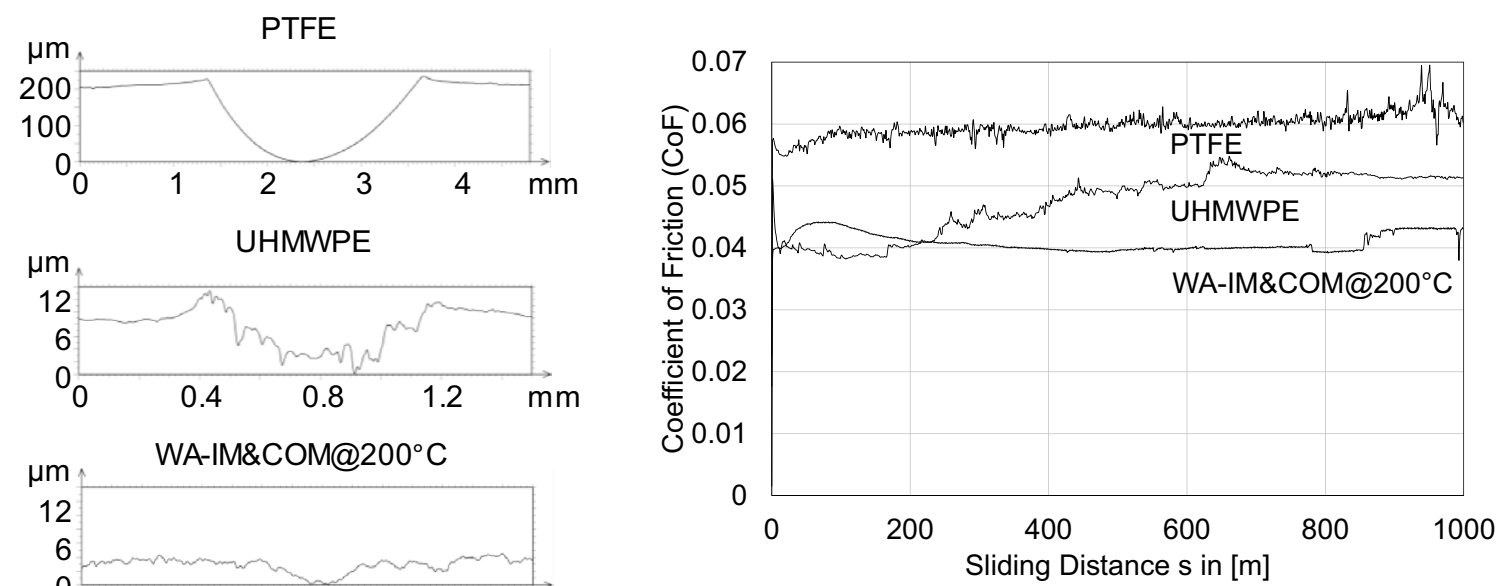

Fig. 8 Measured wear profiles (Left) and CoF (Right) after sliding distance s of $1000 \mathrm{~m}$

the highest particle removal occurs at GG-WA(17 wt\%)IM\&COM. With the exception of this one modification (GG$\mathrm{WA}(17 \mathrm{wt} \%)-\mathrm{IM} \& \mathrm{COM})$, a significant reduction in wear for the compressed samples is achieved regardless of the filled or coated material. The $\mathrm{k}$ values range from $2.9 \times 10^{-7}$ to $6.5 \times 10^{-7} \mathrm{~mm}^{3} / \mathrm{N} \mathrm{m}$. The WA-IM\&COM variants have similar wear properties, even though the friction characteristics are different. Of these, the lowest wear was exhibited by WA-IM\&COM@ $200{ }^{\circ} \mathrm{C}$. The lowest $\mathrm{k}$ value of all samples is $2.9 \times 10^{-7} \mathrm{~mm}^{3} / \mathrm{N} \mathrm{m}$ for the variant GG-IM\&COM\&GR$\mathrm{COA}$, which also has the highest hardness of all the samples studied.

Despite the approximately equal hardness and quantitatively higher wear particle presence in GR-COA to WA-IM, this modification suffers substantially less wear than WA-IM. A possible explanation could be due to the fact that for GR-COA samples, the cellulose fibers are bent by the tribological stress resulting in partial compression. These pressed fibers can then interlock with each other eventually forming new microcrystalline bundles and hydrogen bonds, resulting in increased hardness. For WA-IM, this may not be possible due to wax in the interspaces between the fibers. The low wear exhibited by beeswax can be explained using its properties. Beeswax plasticizes due to heat development in the contact region, thereby wetting the surface and promoting sliding of the fibers against each other and, thus, preventing further bonds from forming. This could lead to the plastic deformation shown in Table $2 \mathrm{~d}$, where no wear debris was discernible.

The significantly increased wear resistance of the compressed samples is also attributed to the hardness. As already described in 3.1, the sample body has more material per unit area to support a load acting upon it. Additional filling with GG does achieve a significant increase in hardness, but it does not cause a proportional increase in wear resistance. With GG and beeswax-filled samples, the opposite occurs, which is illustrated at the end of the measurement by increased friction and wear values (Fig. 7). This can be explained by thermal softening. Unlike a graphite-coated sample, there is no separate solid lubricant layer between the base and counter body. This creates a direct contact that slides on the filled body. It is assumed that the resulting heat input causes beeswax-dominating areas to plasticize more quickly and spread out as an initial lubricating film. As a result, there are gaps in the material matrix, which promote the detachment of animal glue micro-particles. Due to their relatively high hardness, these lead to abrasive wear on the sample body. The steel sphere (not shown) also displayed wear grooves not seen in the variants without animal glue. This explanation is supported by considering the different melting temperatures of the two solids. In our own experiments, these two additives were heated in separate containers. Beeswax showed a first plasticization from a temperature upwards of $60{ }^{\circ} \mathrm{C}$ and was in liquid form above $65^{\circ} \mathrm{C}$. Animal glue, however, showed no softening when dried, even at a temperature of $100{ }^{\circ} \mathrm{C}$ and an exposure time of over $24 \mathrm{~h}$. On the WA-IM\&COM samples, the increased drying temperature showed a positive effect on the friction and wear behavior. This is attributed to the increased hardness of the WA-IM\&COM@ $200{ }^{\circ} \mathrm{C}$ variant.

Finally, the wear tracks for the modified wood resulting in the lowest friction and wear (WA-IM\&COM@200 ${ }^{\circ} \mathrm{C}$ ) was compared under similar test conditions $(10 \mathrm{~N}$ normal load, $0.1 \mathrm{~m} / \mathrm{s}$ sliding speed, $50 \%$ relative humidity for $1000 \mathrm{~m}$ ) with PTFE and ultra-high-molecular-weight-polyethylene (UHMWPE). Figure 8 (Right) shows the CoF values measured against a $100 \mathrm{Cr} 6$ steel sphere of $6 \mathrm{~mm}$ diameter. The friction of WA-IM\&COM@ $200{ }^{\circ} \mathrm{C}$ is the lowest of the three. It is also the steadiest. The wear profiles measured after the experiment are also shown (Fig. 8-Left). Wear volumes, 
determined with these profiles, gave a $\mathrm{k}$ value for modified beech wood of $3.4 \times 10^{-6} \mathrm{~mm}^{3} / \mathrm{N} \mathrm{m}$. This value is 3 times less than UHMWPE and 290 times less than PTFE sliding against 100Cr6.

This clearly indicates that this modification of beech wood can compete from a tribological viewpoint with wellestablished synthetic polymers. These renewable natural products are, theoretically, available indefinitely. Wood products are considered climate friendly and $\mathrm{CO}_{2}$ neutral. Only the harvest of the material and its subsequent processing into a product result in a separate energy input.

Further investigations are in progress to investigate the effects of water upon the tribological and mechanical behavior of modified wood as well to incorporate recent studies on the hydrophobization of wood [15, 34] with wax-impregnated and compressed wood developed in this paper.

\section{Conclusions}

This study demonstrates that it is possible to drastically reduce friction and wear between steamed beech wood and steel by using selected additives combined with suitable processes.

Beeswax-impregnated and compressed wood samples (WA-IM\&COM@200 ${ }^{\circ} \mathrm{C}$ ) exhibit the lowest friction as well as low wear. Under the tested tribological parameters, the CoF values (0.03-0.04) against 100Cr6 steel spheres are comparable to PTFE and UHMWPE, while exhibited wear is lower than PTFE (290 times) and UHMWPE (3 times).

The lowest overall wear was measured for animal gluefilled and compressed wood samples that were subsequently coated with graphite (GG-IM\&COM\&GR-COA). These were also the hardest of all the examined wood samples. However, all the graphite-coated wood samples showed higher friction with increasing sliding distance due to depletion of graphite in the contact region.

Acknowledgements Open Access funding provided by Projekt DEAL.

Open Access This article is licensed under a Creative Commons Attribution 4.0 International License, which permits use, sharing, adaptation, distribution and reproduction in any medium or format, as long as you give appropriate credit to the original author(s) and the source, provide a link to the Creative Commons licence, and indicate if changes were made. The images or other third party material in this article are included in the article's Creative Commons licence, unless indicated otherwise in a credit line to the material. If material is not included in the article's Creative Commons licence and your intended use is not permitted by statutory regulation or exceeds the permitted use, you will need to obtain permission directly from the copyright holder. To view a copy of this licence, visit http://creativecommons.org/licenses/by/4.0/.

\section{References}

1. Czichos, H., Habig, K.-H.: Tribologie-Handbuch. Vieweg+Teubner Verlag, Wiesbaden (2010)

2. Waßmann, O., Weigel, K., Geitel, N., et al.: Reibung und Verschleiß von PTFE gegen unterschiedliche tribologische Beschichtungen. Tribologie + Schmierungstechnik. Jahrgang 3, 45-52 (2018)

3. Kole, P.J., Löhr, A.J., Van Belleghem, F.G.A.J., et al.: Wear and tear of tyres: a stealthy source of microplastics in the environment. Int. J. Environ. Res. Public Health 14, 1265 (2017). https://doi. org/10.3390/ijerph14101265

4. Sajid, M., Ilyas, M.: PTFE-coated non-stick cookware and toxicity concerns: a perspective. Environ. Sci. Pollut. Res. 24, 2343623440 (2017). https://doi.org/10.1007/s11356-017-0095-y

5. Brockman, W.T.: Combat legend: de Havilland Mosquito. Air Power Hist. 51(1), 57 (2004)

6. Fraunhofer, W.K.I.: Holzformteile als Multi-Materialsysteme für den Einsatz im Fahrzeug-Rohbau (HAMMER). Schlussbericht: HAMMER (2016). https://doi.org/10.2314/GBV:874862787

7. WOODEX (BEARING COMPANY; INC.). WasserturbinenLagerung. Online: http://woodexbearing.com/product/oil-impre gnated-wood-bearings-for-hydro-turbines (2019). Accessed 30 July 2019

8. Niemz, P., Sonderegger, W.: Holzphysik-Physik des Holzes und der Holzwerkstoffe. Carl Hanser Verlag, München (2017)

9. Wagenführ, A., Scholz, F.: Taschenbuch der Holztechnik. Carl Hanser Verlag, 3. Auflage, Leipzig (2018) https://doi. org/10.3139/9783446431799

10. Schwab, E.: Die Härte von Laubhölzern für die Parkettherstellung. Holz als Roh- und Werkstoff 48, 47-51 (1990). https://doi. org/10.1007/BF02610703

11. IaFB e.V.: Verdichtetes Holz. Merkblatt-HHT-M.07- Hochleistungsholztragwerke vom Institut für angewandte Forschung im Bauwesen e.V. (2010)

12. Kollmann, F.: Technologie des Holzes und der Holzwerkstoffe, zweite Auflage, erster Band. Springer, Berlin (1951)

13. Ozyhar, T.: Moisture and time dependent orthotropic mechanical characterization of beech wood. Dissertation, Zürich (2013) https ://doi.org/10.3929/ethz-a-009787740

14. Ferreira, A.M., Pereira, J., Almeida, M., et al.: Low-cost natural binder for particleboards production: study of manufacture conditions and stability. Int. J. Adhes. Adhes. (2019). https://doi. org/10.1016/j.ijadhadh.2019.01.019

15. Scholz, G., Krause, A., Militz, H.: Volltränkung modifizierten Holzes mit Wachs. Eur. J. Wood Prod. 70, 91-98 (2012). https:// doi.org/10.1007/s00107-010-0485-Z

16. Bekhta, P., Hiziroglu, S., Shepelyuk, O.: Properties of plywood manufactured from compressed veneer as building material. Mater. Des. 30, 947-953 (2009). https://doi.org/10.1016/j.matde s.2008.07.001

17. Song, J., Chen, C., Zhu, S., et al.: Processing bulk natural wood into a high-performance structural material. Nature 554, 224-228 (2018). https://doi.org/10.1038/nature25476

18. Gan, W., Chen, C., Kim, H.-T., et al.: Single-digit-micrometer thickness wood speaker. Nat. Commun. 10, 5084 (2019). https:// doi.org/10.1038/s41467-019-13053-0

19. Gan, W., Chen, C., Wang, Z., et al.: Dense, self-formed char layer enables a fire-retardant wood structural material. Adv. Funct. Mater. 29, 1807444 (2019)

20. Frey, M., Schneider, L., Masania, T., Keplinger, T., Burgert, I.: Delignified Wood-Polymer Interpenetrating Composites Exceeding the Rule of Mixtures. ACS Appl. Mater. Interfaces. (2019). https://doi.org/10.1021/acsami.9b11105 
21. Vorreiter, L.: Gehärtete und mit Metall oder Öl getränkte Hölzer. Holz als Roh- und Werkstoff (1942). https://doi.org/10.1007/ BF02605309

22. Sathre, R., Gorman, T.: Improving the performance of wooden journal bearings. For. Prod. J. 55(11), 41 (2005)

23. Hamdan, S., et al.: Wear of wood polymer composite for journal bearing materials. Wood Res. J. 1(1), 22-26 (2010)

24. Kim, S.S., Yu, H.N., Hwanget, I.U., et al.: Characteristics of wood-polymer composite for journal bearing materials. Compos. Struct. 86(1-3), 279-284 (2008)

25. Hull, W.Q., Bangert, W.G.: Animal glue: a staff-industry collaborative report. Indust. Eng. Chem. 44(10), 2275-2284 (1952)

26. Skyba, Oleksandr: Durability and physical properties of thermohygro-mechanically(THM)-densified wood. Dissertation. Zürich (2008) https://doi.org/10.3929/ethz-a-005685999

27. Metzger, M. T.: Naturnahe Bindemittel aus nachwachsenden Rohstoffen auf Proteinbasis zur Herstellung von Holzwerkstoffen. Dissertation, München (2007) https://nbn-resolving.org/urn/ resolver.pl?urn:nbn:de:bvb:91-diss-20080128-645700-1-1

28. Bowden, F.P., et al.: Friction of diamond, graphite and carbon and the influence of surface films. R. Soc. (1951). https://doi. org/10.1098/rspa.1951.0173

29. Denninger, Edgar: Über Doublierungsklebstoffe. Nachrichtenblatt der Denkmalpflege in Baden-Württemberg-Organ der Staatlichen Ämter für Denkmalpflege, Bd. 8, Nr. 3, S.70 (1965) https://doi. org/10.11588/nbdpfbw.1965.3.14960
30. Seher, A., Lange, J. Gemeinschaftsarbeiten der DGF, 60. Mitteilung Deutsche Einheitsmethoden zur Untersuchung von Fetten, Fettprodukten und verwandten Stoffen, 45. Mitt.: Analyse von Wachsen und Wachsprodukten X (1974) https://doi.org/10.1002/ lipi.19630650713

31. Benedix, R.: Bauchemie-Einführung in die Chemie für Bauingenieure und Architekten. Springer Vieweg, 6. Auflage, Wiesbaden (2015) https://doi.org/10.1007/978-3-658-04144-1

32. Gesellschaft für Tribologie e.V.: Arbeitsblatt 7-Tribologie Definitionen, Begriffe, Prüfung. S. 37 (2002) Link: https://www.gft-ev. de/de/arbeitsblaetter/

33. Lancaster, J.K.: Dry bearings: a survey of materials and factors affecting their performance. Tribology 6(6), 219-251 (1973). https://doi.org/10.1016/0041-2678(73)90172-3

34. Yang, M., Chen, X., Lin, H., et al.: A simple fabrication of superhydrophobic wood surface by natural rosin based compound via impregnation at room temperature. Eur. J. Wood Wood Prod 76, 1417-1425 (2018)

Publisher's Note Springer Nature remains neutral with regard to jurisdictional claims in published maps and institutional affiliations. 